\title{
The Literary Legacy of Rupert Hughes
}

\section{J A M E S O. K E M M}

Superlatives were plentiful when Rupert Hughes was honored at a testimonial dinner in the Ambassador Hotel ballroom in Los Angeles. It was a "whopping party," according to the Los Angeles Examiner, saying, "In one way or another, some 500 people, blessed with the experience of personal contact with the brilliant mind of the noted author, historian, and playwright, paid him homage." 1

The Los Angeles Times reported that "Rupert Hughes-author, historian, musician, soldier - was praised last night for his years of 'great service' by a host of writers, actors, military, and political figures and friends." ${ }^{2}$ Film star Pat O'Brien was master of ceremonies at the January 9, 1950, dinner sponsored by The Authors, The Lambs, and The Masquers - top Hollywood organizations reflecting the talents of the motion picture industry. Eulogizing the 78-year-old Hughes were California Governor Earl Warren, film magnate Louis B. Mayer, movie personalities Ed Wynn and Edward Arnold, scores of literary figures and others. Pat O'Brien called the tribute "long overdue," and the Examiner said a typical comment by speakers was that the honoree was "One of the outstanding Americans to whom more honor is due than he can ever be accorded."

The belated tribute for the Missouri-born Rupert Hughes, who grew up in Keokuk, Iowa, capped a career of more than 60 years that brought great success and much acclaim, along with some harsh criticism as he fought for causes in which he believed.

Rupert Hughes was interested in everything and everybody, he often said, and he wished he could live to be a thousand years old, in order to write all the stories he wanted to produce. ${ }^{4} \mathrm{He}$ could switch easily from one subject to another totally unrelated, in writing more than 60 books;

\footnotetext{
${ }^{1}$ Los Angeles Examiner, January 10, 1950, Part 2, p. 1.

${ }^{2}$ Los Angeles Times, January 10, 1950, Part 1, p. 2.

${ }^{3}$ Los Angeles Examiner, January 10, 1950, Part 2, p. 1.

${ }^{4}$ Los Angeles Times, September 10, 1956, p. 1.

Copyright 1984, James O. Kemm
} 
a sophisticated novel about New York would be followed by a poignant tale of a simpler time in a small midwestern town. Along the way, he wrote countless short stories, articles, poems, nonfiction books, plays, music, and a three-volume biography of George Washington; and nearly 50 silent and sound motion pictures carried his name as writer and/or director or were based upon his novels and stories.

Few authors in American literary history have matched his prodigious output. Whether his work would survive he had no idea; even if another Shakespeare were alive and productive in the twentieth century, no one would realize it for 300 years, he contended. ${ }^{5}$

As a youngster, there seemed little doubt that Rupert Hughes would become a writer. His first poem was published when he was seven, before he moved from his birthplace of Lancaster in northeastern Missouri to Keokuk, Iowa. The son of Felix and Jean Hughes, he was born on January 31,1872 , in a one-story wooden frame house, since stuccoed, where his sister and three brothers were also born.

Felix Turner Hughes taught school without a college education and studied in a law office in Memphis, Missouri, where he met Jean Amelia Summerlin and married her in 1865 . They moved to Lancaster, he set up a law practice, and they began a family. Their firstborn was a daughter, Greta, followed by four sons, Howard Robard, Rupert, Felix, and Reginald. Two others were born in Keokuk, where the family moved in 1880 , but both succumbed as infants, and Reginald died at the age of 5 .

With their mother's encouragement and father's financial backing, each of the four who survived to adulthood achieved notable success. Greta grew to be a tall, stately beauty with a soprano voice that matched. She studied voice in New York and Paris, where she lived for some years and launched a promising career in grand opera and concerts under the name of Jeanne Greta. She was married to Herbert Witherspoon, a Metropolitan Opera bass who, years after their divorce, became the Met's general manager. A voice teacher in New York in her final years, Greta died in 1916 of tuberculosis.

Young Felix studied music in Europe, became a well-known vocalist, one of the founders of the Cleveland Symphony, a composer, and an internationally recognized teacher of voice in New York and later in Los Angeles.

For Howard it was more difficult to find his niche. He went to Harvard for awhile and studied law for a year at the State University of Iowa. Without graduating, he began to practice law with his father but soon headed

\footnotetext{
${ }^{5}$ Letter from Rupert Hughes to Waitman Barbe, May 13, 1920, in the Waitman Barbe papers at the West Virginia and Regional History Collection, West Virginia University Library.
} 
for the gold and silver mines, then to Joplin, Missouri, to try lead and zinc mining. When he heard the news of the Spindletop oil discovery in Texas, he rushed to the area and went into the oil drilling business. Within a few years he invented the conical rotary bit that revolutionized drilling. Rupert wrote later that Howard designed the device at his parents' kitchen table during a visit to Keokuk. ${ }^{6}$

The Sharp-Hughes Tool Company cofounded by Howard Hughes and Walter Sharp (later the Hughes Tool Company) became the inheritance of Howard's 18-year-old son. Howard Robard Hughes, Jr., the recordbreaking pilot, industrialist, and Hollywood producer, in turn became the reclusive billionaire whose death in 1976 started a scramble for the fortune he left.

In Keokuk, where Felix Turner Hughes served as mayor, a judge, and was president of the Keokuk and Western Railroad, the Hughes family lived in a new three-story brick home at 312 North Fifth, a few blocks from the Mississippi River, and Rupert's education at the public elementary school was augmented by learning about Greek sculpture and Italian art at his mother's knee. Plays he wrote as a boy were performed in the Hughes living room, and by the time he reached his teens he spoke Latin fluently.

At school in Keokuk and at military boarding school in St. Charles, Missouri, Rupert was nicknamed History because of his scholarly appearance, and the term stuck with him at Adelbert College in Cleveland, Ohio (now Western Reserve University), where he earned a bachelor of arts degree in 1892 after winning a Phi Beta Kappa key. He then studied music and literature at Yale, intending to earn a doctorate and become a professor of English literature, but settled for a master of arts degree and began a writing career as a reporter for the New York Journal.

Shortly before turning 22, Rupert Hughes married Agnes Wheeler Hedge of Syracuse, New York, whom he had met a few months earlier. He telegraphed his intentions to his father, who sent his blessing and $\$ 500$ and provided an allowance to the couple for years. ${ }^{7}$ Within the next year, Rupert edited Storiettes and spent time free-lancing, then for four years worked successively as assistant editor for Godey's Magazine, Current Literature, and the Criterion. His ambitions also led to the stage.

Turning again to his father, he sought financial backing, and Judge Felix Hughes advanced $\$ 2,500$ for his son's one-half share of the production of The Bathing Girl, a musical comedy for which Rupert wrote the libretto.

\footnotetext{
${ }^{6}$ Rupert Hughes, "My Father," American Magazine, August 1924, p. 70. ${ }^{7}$ Ibid.
} 
Its opening in 1895 at the Fifth Avenue Theatre in New York won distinction, but not the kind for which Rupert had hoped. It lasted one night. ${ }^{8}$

Although magazines were buying his essays, sonnets, and criticisms of art and music, he found it difficult to sell fiction until 1897, when St. Nicholas Magazine published some stories he had written for boys, based upon his remembrances. The Century Company published the stories the next year in his first book, The Lakerim Athletic Club; two other Lakerim books were published later, and sales of at least a few copies annually continued a half-century later.

The year 1897 was important to Rupert Hughes in other ways, too. His wife gave birth to their only child, a daughter named Elspeth, and he enlisted as a private in the New York National Guard, beginning a long military involvement.

Some of his most enduring work consists of books about music written in the early part of his career. An excellent musician himself, his American Composers, published in 1900, has been called "a standard account of the development of music in this country up to the date of publication."9

Hughes's other books about music and musicians, mostly written in the early 1900s, included Love Affairs of Great Musicians (1903) and Songs by Thirty Americans (1904). The Musical Guide, a 1903 two-volume encyclopedia revised in one volume in 1912 as Music Lovers' Cyclopedia, was called by Nation ". . . in some respects the most comprehensive and useful of all musical works of reference." 10 It was revised in 1939 by Deems Taylor and Russell Kerr as Music Lovers' Encyclopedia and has been reprinted many times. In addition, Hughes composed many songs.

$\mathrm{He}$ achieved early recognition as a poet with his lengthy dramatic monologue Gyges' Ring in 1901. Its "classical theme and a literary quality . . . has placed it among permanent literature," in the view of the $\mathrm{Na}$ tional Cyclopedia of American Biography. ${ }^{11}$ It was republished in 1949 in Hughes's Gyges' Ring and Other Verse. Some of his poems include "For Decoration Day" and "With a First Reader," both published in anthologies; a touching sonnet and a tender elegy in memory of his sister; and the humorous "The Happiest Man in I-O-Way." He donated the manuscript of "The Christmas Rendezvous," published in 1950 by Good

\footnotetext{
${ }^{8}$ Ibid.

${ }^{9}$ Living Authors, edited by Dilly Tante (New York: H. W. Wilson Company, 1931), p. 187.

${ }^{10}$ The Nation, volume 1, p. 372, April 10, 1913, as excerpted in Book Review Digest, 1913.

"'The National Cyclopedia of American Biography (New York: James T. White Company, 1930), volume C, p. 315.
} 
Housekeeping, to Special Collections at The University of Iowa Libraries. $^{12}$

His early work as a historian began in 1901 with an 18-month assignment in London and Paris and another three and a half years in New York as chief assistant editor of The Historians' History of the World. published in 25 volumes by the Encyclopredia Britannica. Meanwhile, he kept busy writing plays.

Rupert Hughes never met with much success as a playwright until 1909, although not for lack of trying. Starting in 1902, at least eight plays he wrote were produced during the next six years in New York, London, or elsewhere, including Alexander the Great, which toured the U.S. for a year but did not reach New York.

Divorced from his first wife in 1904 after a much-publicized court batthe that ended in shared custody of their daughter, Hughes was married in 1908 to the beautiful Adelaide Mould Bissell, a divorcee and mother of two children. He cast Adelaide as the leading lady in the 1908 New York production of his All for a Girl, with Douglas Fairbanks in his first New York starring role.

The Bridge in 1909 was a boost to Hughes's reputation as a playwright, running 33 performances in New York, then touring as The Man Between for three years. In 1910, Two Women, adapted by Hughes from the Italian, starred the famous Mrs. Leslie Carter, ran in New York for 47 performances and went on tour for three seasons.

The most notable stage triumph for Hughes was an unlikely vehicle called Excuse Me, a Pullman car farce that opened in February 1911; it was one of only three plays that lasted more than 150 performances in New York that year, topping out at 160 . A book version, illustrated by James Montgomery Flagg, was also published, while the stage play proved so popular that four companies toured the U.S. in 1911-12, two others from 1912 to 1914; and it was produced in Australia in 1913 and in London in 1915. Two movie versions later were quite successful, and in 1918 a Broadway musical comedy version, called Toot-Toot!, featured the music of Jerome Kern.

Two of the seven other plays by Rupert Hughes produced between 1909 and 1920 were a stage version of the Grace Miller White novel Tess of the Storm Country in 1911 and his last New York play, The Cat-Bird, starring John Drew in 1920. He also wrote one-act plays and vaudeville sketches, including the stage version of Miss 318 , on tour for many years.

\footnotetext{
${ }^{12}$ Letter from Rupert Hughes to Grace Van Wormer, dated August 5, 1950, in The University of lowa Libraries Special Collections.
} 
When Rupert Hughes started selling his short stories, he found a ready market in leading popular magazines. In the Index to Short Stories, Second and Enlarged Edition, published in 1923, the Hughes stories total 83. An additional 13 were listed in a 1929 supplement.

Some of the most successful books by Rupert Hughes were collections of his short stories, including In a Little Town, published in 1917, with 14 stories about people in imaginary towns near Keokuk. A reviewer for the New York Times praised the tales, saying the author "finds vices as well as virtues among the people of these village streets.... But Mr. Hughes writes about them all with that tenderness of touch that comes of full comprehension." 13

Soon after, he signed a contract for Hearst's Magazine to take his output of short stories for a year that was "the highest priced contract given to a short story writer," according to a letter in the Special Collections at The University of Iowa Libraries. ${ }^{14}$

At about this time, the 69th Regiment, in which Rupert Hughes had worked his way up to the rank of captain, went to France without him, because of his slight hearing impairment. Terribly disappointed, he dedicated a 1918 collection of Irish stories - inspired by the enlisted men of the regiment - to "The Fighting 69th, now the 165th Infantry, With Homage and Envy." Entitled Long Ever Ago, it was included among the year's ten best books of short stories in Edward J. O'Brien's The Best Short Stories of 1918 and praised by O'Brien as "the definitive chronicle of the first Irish American generation in its process of assimilation by New York." 15 O'Brien also named one of the stories, "At the Back of God Speed," to the Roll of Honor for 1918. In the same year, Hughes's The Fairy Detective, containing stories for small children, was also published.

One of the most-acclaimed short stories by Rupert Hughes was "The Stick-in-the-Muds," included among 13 stories published by Harper in 1920 in Hughes's Momma, and Other Unimportant People. With the mythical midwestern town of Carthage as a locale, it tells the story of an aspiring writer's unfulfilled dreams. It was reprinted in O'Brien's Best Short Stories of 1920 and as one of The World's 100 Best Short Stories in the ten-volume all-time anthology by that name, compiled by Grant Overton for Funk \& Wagnalls in 1927-along with stories by Tolstoy, Hawthorne, Balzac, and De Maupassant.

\footnotetext{
${ }^{13}$ New York Times, March 18, 1917, Section VIII, p. 93.

${ }^{14}$ Letter from Rupert Hughes to Gordon Ray Young, March 11, 1917, in Special Collections, The University of lowa Libraries.

${ }^{15}$ The Best Short Stories of 1918 and the Yearbook of the American Short Story, edited by Edward J. O'Brien (Boston: Small, Maynard \& Company, 1919), p. 358.
} 
Another story from Momma, entitled "The Father of Waters," was designated one of The World's 50 Best Short Novels in a ten-volume compilation by Overton, published in 1929 by Funk \& Wagnalls, along with such stories as Charles Dickens's "A Christmas Carol."

In much of his writing, Hughes conveyed a feeling of immediacy. Influenced by the novels of Henry Fielding, he wanted to show all aspects of New York life, as Fielding had done for London. ${ }^{16}$ Hughes did this first with his 1904 The Real New York, vividly portraying both the fashionable and seamy sides of the city. It is well worth reading today as social history.

The first published novel by Rupert Hughes, in 1902, was a Civil War story with a Missouri setting, called The Whirlwind, followed by Zal (1905), about a Polish pianist.

Many of the most delightful stories by Rupert Hughes were novelettes. Several were seasonal, such as Col. Crockett's Co-operative Christmas; Mrs. Budlong's Christmas Presents; and Miss 318. The latter was an engaging 1911 story of the Christmas season as viewed by a harried shopgirl in New York. The New York Times praised it for "much humor, some of it rather riotous, and flashes of real wit," and its publication helped bring improved working conditions for department store employees across the nation. ${ }^{17}$ It was followed by a sequel, Miss 318 and Mr. 37, and several other novels during the next few years, including The Gift Wife, The Lady Who Smoked Cigars, and The Amiable Crimes of Dirk Memling.

But it was in The Old Nest in 1912 that the ability of Rupert Hughes to stir emotions became most apparent. Knowing his mother's loneliness for her family, he found the inspiration for a simply told story about a devoted father and mother in a small midwestern town who are neglected by their children - all successful in careers far away. The joy of their eventual reunion tugged at the heartstrings of readers, and an amazed Rupert Hughes told the Bookman he did not realize what he had done until letters, telegrams, and floral tributes arrived at his door from throughout the nation. It was estimated that some 20,000 young men had returned home, besides those who had telephoned, telegraphed, or worn white carnations. ${ }^{18}$ The critics were virtually unanimous in praising The Old Nest.

Another Hughes short novel, The Last Rose of Summer, about an elderly spinster in a little town who finally finds love, was described by the New York Times as a "very dainty, very charming little story . . . told with skill and humor." 19

\footnotetext{
${ }^{16}$ Rupert Hughes, "An Autobiography by Request," in The Men Who Make Our Novels, by George Gordon (New York: Moffat, Yard \& Company, 1919), p. 42.

${ }^{17}$ New York Times, December 3, 1911 , Part 6, p. 762.

${ }^{18}$ Bookman, May 1927, p. 360.

${ }^{19}$ New York Times, November 22, 1914, Section VI, p. 517.
} 
A much different style was undertaken by Hughes with great success in What Will People Say?, published serially in Red Book magazine and then in book form by Harper \& Brothers in 1914. The heroine's easy moral code shocked some readers, but Bookman praised the "scene after scene of photographic vividness" and the "sense of depth and atmosphere" in the novel, which ranked at or near the top of best-seller lists in many cities. It reached second on Bookman's nationwide list and remained in the top six for many months. ${ }^{20}$

Prior to U.S. involvement in World War I, several other successful novels were penned by Hughes, each reflecting current headlines and trends. Before he completed Empty Pockets, a New York murder mystery, war broke out in Europe, so Hughes sent the heroine overseas as a war nurse. Another best-seller was Clipped Wings (1916), called by actors "the only fair portrait of the stage of our time." It was also, Hughes said "incidentally an enthusiastic brief for a woman's rights to a career apart from family ties." ${ }^{21}$ The Thirteenth Commandment (1916) used the war in Europe as a backdrop for the intertangling of the love interest and the desire of New Yorkers for money, with Hughes calling for every girl to learn a trade.

The serialization of his novels by Red Book before their publication by Harper \& Brothers and, in fact, even before their completion, enabled the author to include timely events as background or plot material. When he was sent to the Mexican border with his regiment in 1916, installments of We Can't Have Everything were already being published, so Hughes had to spend long hours at night working on the novel, in which Hughes made a plea for easy divorces and sent the main male character to the Mexican border. ${ }^{22}$ While serving in Albany as assistant to the New York adjutant general, Captain Hughes began The Unpardonable Sin, about two defenseless American women in German-occupied Belgium. The book's horror stories of German occupation were defended in a New York Times editorial, after a report of censorship by a New York library, as completely documented. ${ }^{23}$

Assigned to Military Intelligence in Washington, D.C., in early 1918 , Hughes soon was promoted to major and remained there until 1919,

\footnotetext{
${ }^{20}$ Bookman, January 1915, p. 482.

${ }^{21}$ Rupert Hughes, "An Autobiography by Request," p. 48.

${ }^{22}$ Ibid., p. 47. Also, Rupert Hughes, "Early Days in the Movies," Saturday Evening Post, April 13, 1935, p. 31.

${ }^{23}$ New York Times, September 3, 1918, p. 10.
} 
spending off-duty hours writing The Cup of Fury (1919), a novel about the shipbuilding frenzy. ${ }^{24}$

During the decade of the 1920s, Rupert Hughes continued to turn out a novel each year, including What's the World Coming To?, a story of postwar New York; Souls for Sale, about a young woman who disappears into the land of filmmaking and sacrifices everything to become a star; and The Old Home Town, his longest story about Carthage. Although opinions differed as to which novel was his best, at least three were called that during this period by at least one critic in each instance: Within These Walls (1923), The Golden Ladder (1924), and Destiny (1925). His other novels in the 1920s were Beauty (1921), We Live But Once (1927), The Lovely Ducklings (1928), and Mermaid and Centaur (1929).

A half-dozen novels were written by Hughes in the 1930s, including Ladies' Man; No One Man; and The Woman Accused (which he wrote in a collaborative effort with nine other successful authors, including Zane Grey, Irvin S. Cobb, and Gertrude Atherton). All were made into movies. His Love Song (1934) won rave reviews for its enthralling story of a midwestern soprano's rise to stardom with the Metropolitan Opera. It moved Margaret Wallace of the New York Times to write, "Without doubt, 'Love Song' is the best novel Rupert Hughes has yet given us, and it has an excellent claim to the further distinction of being the best musical novel so far produced in America." 25 Two historical novels by Hughes also were published in the 1930s, including The Man without a Home, about John Howard Payne, author of "Home Sweet Home," and Stately Timber, a lengthy and carefully researched chronicle detailing the intolerances of the Puritans. Hughes then turned to the world of Hollywood make-believe in The City of Angels, an almost incredible story of a lifeguard's rise to film stardom.

Rupert Hughes's association with motion pictures began with sales of a short story to Louella Parsons, who then was involved with a film company, in 1907, and Miss 318 and Mr. 37 to Thomas Edison in 1912. Neither was made into a movie, although Edison had planned to use the Hughes story for the first sound film. ${ }^{26}$

The script Hughes had written for the play Tess of the Storm Country was bought for a successful 1914 film starring America's sweetheart Mary Pickford, and the title became such a household word that stock companies begged for the play, resulting in more than 3,000 stage perfor-

\footnotetext{
${ }^{24}$ Rupert Hughes, "Early Days in the Movies," Part 2, Saturday Evening Post, April 13, 1935, p. 118.

${ }^{25}$ New York Times, August 19, 1934, Section V, p. 6.

${ }^{26}$ Rupert Hughes, "Early Days in the Movies," Saturday Evening Post, April 6, 1935, p. 18.
} 


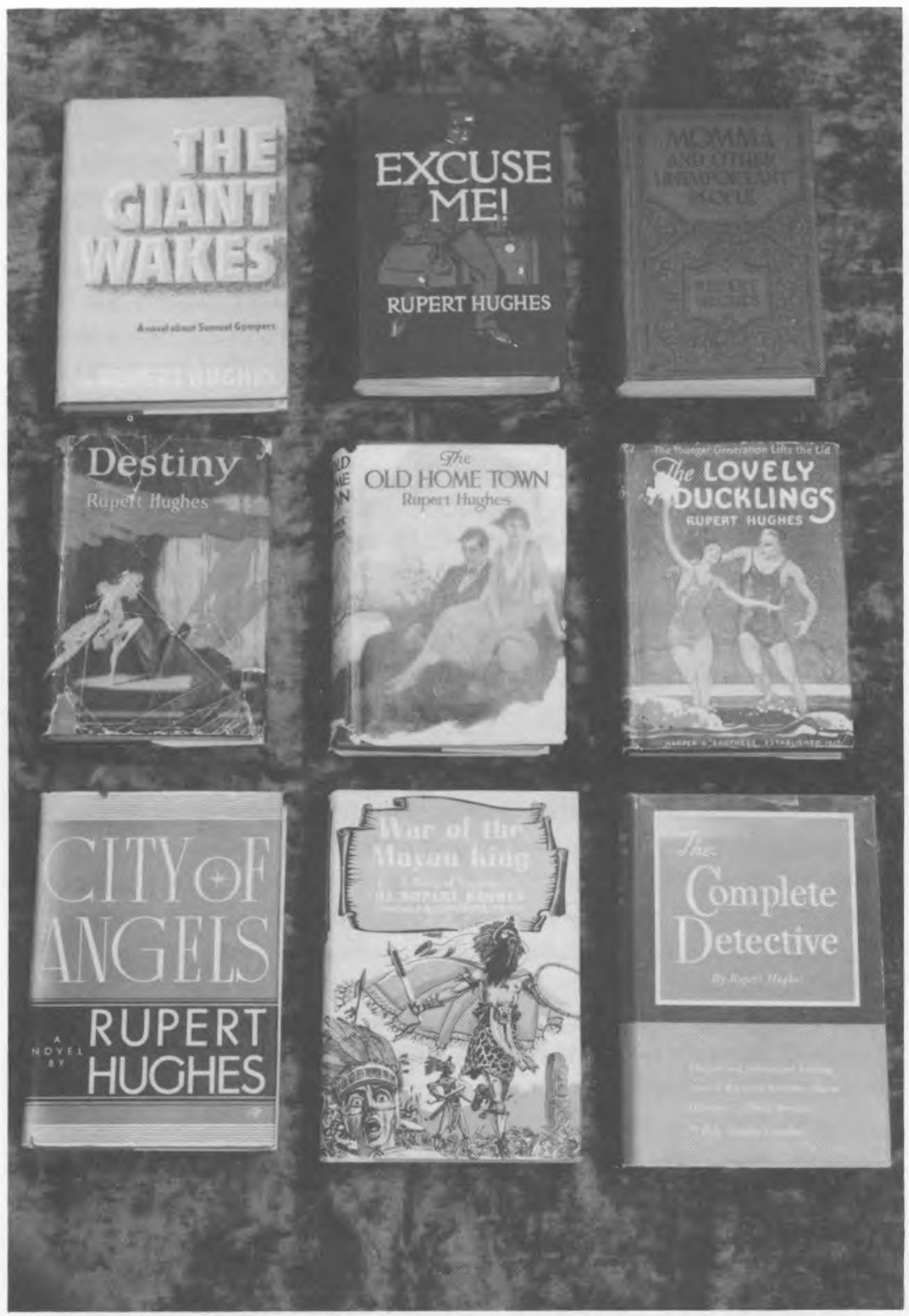

A selection of books by Rupert Hughes from the lowa Authors Collection, The University of lowa Libraries. 
mances. ${ }^{27}$ Another Hughes play, Two Women, was made into a film in 1915.

His first opportunity to write directly for the screen was the scenario for a 1916 serial, Gloria's Romance, starring Billie Burke, which was changed so much by the studio that it was almost unrecognizable in its final form. Hughes saw only the first two episodes at a gala performance on Broadway; critics panned the serial and the audience was bored. ${ }^{28}$ Not even the music of Jerome Kern saved it.

The first of Hughes's novels sold to a motion picture company was What Will People Say?, released in 1915, but the heroine's morals were cleaned up by the producers and the ending altered drastically from that of the novel. ${ }^{29}$ In the same year, Old Folks at Home was also made into a movie.

While on military duty in Albany, Captain Hughes wrote a short story, The Mobilizing of Johanna, about the impact upon a little Dutch girl when a U.S. Army regiment set up camp across from her farm home. Mary Pickford liked the story and made a 1918 movie of it called Johanna Enlists that was very successful.

Samuel Goldwyn, with the aid of Rex Beach, enlisted Rupert Hughes and other leading novelists as Goldwyn Eminent Authors in 1919, at great expense. Included were such literary luminaries as Mary Roberts Rinehart, Gertrude Atherton, and eventually Somerset Maugham among others, but the one most successful in adapting his talents to the screen was Rupert Hughes, who in the early 1920s became known as Hollywood's highest paid author. One of his most successful films was The Old Nest, which won high praise from the New York Times when it opened in New York in 1921. "It's marked sterling in every scene ... go to see it," the reviewer urged. ${ }^{30}$ Goldwyn said the film grossed nearly a million dollars, an enormous sum in those days. ${ }^{31}$

Hughes directed seven motion pictures he wrote for Goldwyn, and his name was displayed prominently in advertising and title cards, as in "Goldwyn presents a Rupert Hughes picture Look Your Best with Colleen Moore and Antonio Moreno, Written and Directed by Rupert Hughes." 32

Miss Moore, who in 1926 became the nation's number one box office attraction, was also in two other Rupert Hughes films in 1922 and 1923,

\footnotetext{
${ }^{27}$ lbid., p. 19.

${ }^{28}$ Ibid., pp. 43-44 31.

${ }^{29}$ Rupert Hughes, "Early Days in the Movies," Saturday Evening Post, April 13, 1935, p.

${ }^{30}$ New York Times, June 29, 1921, p. 10.

${ }^{31}$ Samuel Goldwyn, Behind the Screen (George H. Doran Company, 1923), p. 245.

${ }^{32}$ Title card, showing portrait of Rupert Hughes, for Look Your Best, in James O. Kemm collection.
} 
including Come on Over, which he wrote for her, and The Wall Flower, the first film he directed. More than 60 years later, she recalls Hughes as "very kind" and sensitive to the feelings of cast members. The beautiful Eleanor Boardman, star of Souls for Sale who appeared in three other Hughes films, remembers him for having a brilliant mind and an infinite capacity for work. ${ }^{33}$

Goldwyn wrote in his autobiographical Behind the Screen in 1923, "Mr. Hughes's success in photoplays is to be ascribed to his prompt recognition of the gulf between two channels of expression, literature and screen, and to his determination to master both the technicalities and spirit of the latter." 34

As Hughes's involvement in movie making increased, he and Adelaide moved in the early 1920s to Hollywood. They often entertained at Sunday brunches in their home, with other writers, artists, producers, and film stars on the select list of invitees. Samuel Goldwyn wrote that "some of the happiest hours of my life have been spent in their home." 35

Adelaide had turned to writing poetry and was a coauthor with her husband of the 1923 film Gimme. In ill health, she made a visit to China in 1922 and returned home for an operation. Apparently recovering, she set out again, accompanied by a trained nurse, on an around-the-world trip, but the news came to her husband that she had hanged herself in her stateroom on December 14, 1923, in Haiphong harbor in Indochina. Shocked by the tragedy, he wrote a beautiful memorial for The Poems of Adelaide Manola, published in $1924 .^{36}$

About a year after Adelaide's death, Rupert Hughes married Patterson Dial, an actress in his 1924 motion picture Reno. She also appeared in nearly a dozen other movies and became a writer of short stories for magazines. Through the years she also assisted her husband in many writing projects.

Nearly 50 motion pictures are known to have been made from stories or novels by Rupert Hughes, with as many as seven or eight released in a single year. Many were featured prominently in advertising and reviews in the New York Times, such as The Unpardonable Sin. Most of his popular novels were made into films with such stars as Norma Shearer in $E x$ -

\footnotetext{
"Interview by author with Colleen Moore Maginot at her home near Templeton, California on June 7, 1984; interview with Eleanor Boardman (now the Countess D'Arrast) at her home in Montecito, California on June 9, 1984

${ }^{34}$ Goldwyn, Behind the Screen, p. 245.

${ }^{35}$ Ibid.

${ }^{36}$ The Poems of Adelaide Manola, With a Memorial by Rupert Hughes (New York: Harper, 1924), pp. vii-xix.
} 
cuse Me, and many short stories became the basis of movies, including Tillie and Gus, with W. C. Fields. Stars of other movies based on Hughes plots included Cary Grant and Carole Lombard.

One of the most publicized Hughes films was The Patent Leather Kid in 1927. With Richard Barthelmess as the prizefighter who shows cowardice as a soldier in battle, it was called "an emphatically human chronicle" and "an interesting character study" by a reviewer for the New York Times. ${ }^{37}$ Published as a short novel in 1917, it was republished in 1927 with scenes from the movie. In the film industry's first Academy Awards competition, covering 1927-28, Rupert Hughes was nominated in the writing (original story) category for The Patent Leather Kid, and Barthelmess was nominated for the best actor award for his role in the film.

Rupert Hughes has been quoted as believing his three-volume biography of George Washington was the greatest achievement of his career. ${ }^{38}$ He was prompted to write it by the reaction to a speech in January 1926 at a meeting of the Sons of the Revolution in Washington, D.C., in which he called for truth in history, pointing out some fables about the first president and facts from the Washington diary indicating some of the national hero's human traits. A man in the audience berated Hughes, then provided a garbled account to a newspaper, and the story went across the nation. Hughes was misquoted, castigated by pulpiteers and temperance leaders, and condemned editorially. Despite his protestations that his intentions had been misunderstood and he had, in fact, praised Washington, criticism continued.

To set the record straight, Hughes began his biography based largely upon original research. The first volume in October 1926 called George Washington: The Human Being and the Hero, covered Washington's life to age 30, and the Hughes portrait was viewed by the New York Times as a "highly favorable one, emphasizing his humanness." ${ }^{39}$ The second volume, George Washington: The Rebel and the Patriot, published the next year, covered 1762 to 1777 and told of his growth as a military leader; it was called by a Times reviewer much superior to the first ${ }^{40} \mathrm{~A}$ 1930 volume, George Washington: Savior of the States, 1777-1781, praised Washington's patriotism and lofty motives but criticized his contemporaries for placing stumbling blocks in his way.

Soon Rupert Hughes was making many speeches and writing numerous articles about Washington, continuing his research on the subject for most

\footnotetext{
${ }^{37}$ New York Times, August 16, 1927, p. 31.

${ }^{38}$ New York Times, September 10, 1956, p. 27.

${ }^{39}$ New York Times, October 14, 1926, p. 14.

${ }^{40}$ New York Times, December 11, 1927, Part IV, p. 3.
} 
of the remainder of his life. The biography by Hughes has been praised by other biographers, such as Douglas Southall Freeman and James Thomas Flexner. Although Hughes worked for many years on a fourth volume, it was never completed.

Several other biographies were also written by Rupert Hughes. They were Attorney for the People: The Story of Thomas E. Dewey in 1940, about the prosecutor who later became the Republican presidential nominee; The Giant Wakes, a historical novel about Samuel Gompers, published when Hughes was 78 years old, and winning for him the 1950 book award from the Tamiment Social and Economic Institute; and The Complete Detective, also in 1950, the biography of Raymond Schindler, a pioneer in scientific crime detection.

An indefatigable worker, Rupert Hughes's working habits, acquired early in his career, were well-known to his friends. He got by on very little sleep, and wrote long into the night. Samuel Goldwyn said in 1923 that Hughes "has a capacity for work which I have never seen excelled. Many times I have known him to arrive in the studio early in the morning, direct all day, go home that evening to work on a scenario, and then, after perhaps a dinner or a dance, write several chapters of his new novel." 41

Hughes and his wife, Patterson (whom he called Pat), lived in a mansion they built on Los Feliz Boulevard in an Arabian Nights style, as had been suggested to Hughes by his friend Douglas Fairbanks. In the author's book-lined study, actually a research library, he used as many as five desks at once-one as his Washington desk, while others were for current projects. He wrote everything in longhand in a script sometimes difficult to decipher, and then had it typed by his secretary. He usually destroyed the handwritten version, so few original manuscripts survive. ${ }^{42}$ A surprising amount of his correspondence with writers, editors, historians, and others - some handwritten and some typed as he dictated it - has been preserved, however, in university libraries, historical societies, and other collections throughout the nation, including The University of Iowa.

As a lecturer and after-dinner speaker and toastmaster noted for his wit, he was much in demand. His speeches dealt with many subjects, including foreign affairs, and he became a network radio commentator during the 1940 s for NBC.

Hughes was one of the founders of the California State Guard in 1940, and commanded its Second Regiment as a colonel from 1941 until 1943, when he was 71 years old. He was never afraid to take sides in a con-

\footnotetext{
${ }^{41}$ Goldwyn, Behind the Screen, p. 245.

${ }^{42}$ Letter from Rupert Hughes to Grace Van Wormer, August 5, 1950, in Special Collections at The University of lowa Libraries.
} 
troversy and incurred the wrath of left-wing screenwriters by providing the House Un-American Activities Committee of Congress with names of those he believed to be Communist party members or sympathizers. At other times, he was involved in disputes over unionization of writers.

In 1945, Patterson Dial, his wife for more than 20 years, died of an overdose of sleeping pills, ruled accidental. Her loss was followed a few months later by the death of his daughter. To help overcome his grief, Hughes kept busy with his work, and one of his three granddaughters, Barbara Lapp, came from Cleveland to stay with him for awhile, before her marriage in California. Many years later, she and her sisters were to be named by a Texas court to share in the estate of Howard Hughes, in the absence of a will.

In 1950, Rupert Hughes sold his home on Los Feliz Boulevard and moved in with his brother and sister-in-law, Felix and Ruby Hughes, at their spacious home on North Rossmore. At an age when most authors would have retired to inactivity, in his late 70 s he was still writing fiction. The Triumphant Clay, published when he was 79 , was the story of an architect under the spell of three women. The final novel by Hughes was The War of the Mayan King, published in 1952 when he was 80, but its theme has appeal for young readers. One of a series of Adventure Books issued by the John C. Winston Co., it was included in 1964 on a published list of historical fiction recommended for junior high schools. ${ }^{43}$

After suffering a stroke in 1952 and another a year later, Rupert Hughes continued writing for an inspirational publication, according to a retrospective article by his sister-in-law, almost until the end of his life. ${ }^{44}$

On his eightieth birthday in January 1952, two years after his testimonial dinner, he was honored again by many leading California and local figures. In 1954, because of ill health, he stepped down as president of the Authors Club - a position he had held for all but six months since he founded the group in 1932 - and was named president emeritus.

Looking back at his career from the vantage point of the 1980s, the question can be raised as to why Rupert Hughes has not been given more recognition in recent years for his literary achievements. One answer perhaps is that his subject matter was so universal and he moved so easily from one interest to another, always seeking new avenues for self-expression and creativity, that it is difficult to categorize him. Some literary critics who have viewed him primarily as a successful author of popular

\footnotetext{
${ }^{43}$ Historical Fiction. McKinley Bibliographies Volume I. Compiled by Hannah Logasa. (Philadelphia: McKinley Publishing Co., 1964), p. 166.

${ }^{44}$ Ruby H. Hughes, with Patrick Mahony, "Rupert Hughes (1872-1956): Reflections on His Centennial," Coranto, published by the University of Southern California, 1972, p. 32.
} 
magazine fiction have not always taken his efforts seriously, although contemporary reviewers praised much of his work for its literary quality.

The reading today of his novels and short stories, especially those written during his peak years of productivity from the early 1900 s through the 1920 s, provides an amazing description of life as it was back then. His attention to the vivid details of both New York City and the small Midwest towns in which his plots unfold succeeds in showing the flaws and the virtues of the nation he loved with such patriotic fervor.

The people Rupert Hughes depicted were not drawn so much from his imagination as from his keen observation, and he wrote with a sympathetic understanding. While chronicling the social customs and events of his day, as well as his remembrances of the way things were, Hughes wrote from a perspective of history. At the peak of his career, he told an interviewer, "To me, my novels are just as much history as anything that ever happened." 45

A person desiring today to become acquainted with the fiction of Rupert Hughes will find it rather difficult, as most of his novels, books of short stories, and poetry are no longer readily available at public libraries and book stores, although several of his books have been reprinted in recent years. Fortunately, some university libraries - most notably The University of lowa and the University of Southern California - have built collections of his books and related materials. As one reads this material and learns more about the talents and versatility of Rupert Hughes, it seems entirely possible that some day more of his best stories and novels will be republished and he will be rediscovered as a creative artist.

When death came to Rupert Hughes on September 9, 1956, at the age of 84 after a heart attack while he was seated at his desk, it was front page news in the newspapers of New York, Los Angeles, and Keokuk. His varied achievements were enumerated in the obituaries, which told of his desire to be cremated and for his ashes to be placed beside those of his wife, Patterson Dial, in Forest Lawn Memorial Park in Glendale.

Perhaps the lead paragraph of the Los Angeles Examiner's article summed up the career of Rupert Hughes best, when it called him "for more than 50 years a towering figure in the literary life of the nation." 46

\footnotetext{
${ }^{45}$ Catharine Cranmer, "Rupert Hughes," interview in Missouri Historical Review, October 1925.

${ }^{46}$ Los Angeles Examiner, September 10,1956, p. 1.
} 